\title{
O PLANo INTEgrado de SAúde mental
}

Está sendo entregue ao Ministro da Saúde, para seu estudo e possível encaminhamento à aprovação por meio de Decreto do Presidente da República, o Plano Integrado de Saúde Mental (PISM). Em sua elaboração trabalharam especialistas de vários Estados. Foi inicialmente por eles traçados um diagnóstico do "país no campo da psiquiatria. Os achados incluem o que vai aqui transcrito.

- O PISM deverá abranger de 1977 a 1980.

- $23 \%$ do total de leitos, no país, são para doenças mentais. A proporção está de acordo com os padrões recomendados; entretanto há distorções em sua distribuição entre as Regiões.

- Conta o PISM com oito metas básicas.

- Dentre as metas, uma é a de criar-se um novo modelo de assistência com atendimento predominantemente ambulatorial.

- Será dada ênfase à integração das ações em vários níveis de complexidade crescente (ambulatório, hospital - dia, e hospital - integral).

- A rede de serviços se estenderá desde os lugares com 50.000 habitantes, que deverão dispor de pessoal de saúde de nivel simples, até as metrópoles que deverão dispor de médicos e enfermeiros especializados, outros técnicos e auxiliares técnicos.

- Todo o PISM deverá contar com supervisão e avaliação contínua das ações de saúde, nas cinco Grandes Regiões, - Norte, Nordeste, Sưdeste, Sul e Centro-Oeste.

\section{PESQUISA}

Verbas para pesquisa no valor de Cr\$ 35 milhões já foram em 1977 destinadas ao PISM. São as seguintes as seis pesquisas divisadas: Atitude da Comunidade Frente ao Problema da Saúde Mental; Causalidade das Alterações Mentais segundo o Conceito das Comunidades; Razões Apresentadas pelos Pacientes para Abandonar o Tratamento; Preferência do Tratamento Informal 
(curanderismo e outros) ou Formal, e suas Razões; Atitude das Equipes de Saúde e das de Saúde Mental com Relação ao Doente Mental; e Levantamento de Recursos Humanos Visando a Capacitação de Maior Número de Pessoal. Outra pesquisa deverá ser dirigida à rede atual de atendimento hospitalar psiquiátrico, incluindo recursos materiais e organizacionais bem como recursos em pessoal de todos os Graus ou níveis. Esta última deverá servir de base para a elaboração de projetos de modernização de toda a rede nacional. A OPAS/OMS dará apoio ao PISM.

A finalidade maior da mudança que se planeja é o país ter uma politica de saúde mental compativel com as normas da psiquiatria preventiva.

Em todos os Estados, as lideranças de enfermagem devem procurar divulgar o que pode ser feito para que os enfermeiros desejem assumir sua parte nos trabalhos conjuntos que se anunciam e dos quais o país se beneficiará. (HGD) 